the film (and it is not only in new Ukrainian cinematography) - «Кіборги. Герої не вмирають»(«Cyborgs. Heroes don't

die») which was represented in the Congress of America in 2018, and in 2019 it was released in the USA (the ITN Distribution translated the title as Heroes never die). Now we have a new radio station dedicated to the Ukrainian Army

(events, news, music- Ukrainian, European, American). And the word Justice is more relevant than ever.

\title{
References:
}

1. James Clear. Atomic Habits: An Easy \& Proven Way to Build Good Habits \& Break Bad Ones. October, 16, 2018, 320 p.

2. Comenius: Europe in the Classroom. European Commission: Education and Training. Retrieved 26, November 2011

3. Henry V of England. WikiVidi Documentary https://www.youtube.com/watch?v=dj_JHOgC9m

4. Fred Boycott: John Arlott. The Voice of Cricket https://www.youtube.com/watch?v=86KXiRnnBwQ

5. Philip Hensher. A man for the People. The Guardian, May, 2009. https://www.theguardian.com/music/2009/may/08/peter-grimes-philip-hensher

6. Stephen Farber. Cinema '62: The Greatest Year at the movies, March 13, 2020, $270 \mathrm{p}$.

DOI https://doi.org/10.30525/978-9934-26-039-1-82

\section{ЛЕКСИЧНІ НЕОЛОГІЗМИ ПЕРІОДУ ПАНДЕМІЇ КОРОНАВІРУСУ (НА МАТЕРІАЛІ ІНТЕРНЕТ-ЗМК)}

\author{
Красавіна В. В. \\ кандидат філологічних наук, доцент, \\ доиент кафедри української мови і літератури \\ Національного університету «Чернігівський колегіум» \\ імені Т. Г. Шевченка \\ м. Чернігів, Украӥна
}

Пандемія коронавірусу, яка 3 початку 2020 року поширилася світом і охопила майже 200 країн, викликала стрімкий ріст неологізмів як в українській, так і в інших мовах. Це пов'язано, у першу чергу, iз позамовними чинниками - самою інфекційною хворобою та 
викликаними нею досі не баченими соціальними практиками (карантин, дистанційний режим роботи й навчання), які стали новим способом адаптації до сучасної дійсності. Мова швидко відреагувала на глобальні зміни у світі й суспільстві: з'явилися нові слова, словосполучення на позначення невідомих раніше реалій, явищ, предметів, понять; відбулася модифікація семантичного значення деяких загальновідомих слів; вузькоспеціальні терміни розширили сферу вживання тощо. Більшість неолексем - це медичні та адміністративні терміни, які швидко соціалізувалися й частково адаптувалися в мові завдяки діджиталізації, відкритості інформаційного простору, й перейшли до загальновживаної лексики. Мовна глобалізація, тенденція до уніфікації спричинилася до появи термінів інтернаціонального характеру, неолексем, неоморфем, що свідчить про утворення спільного міжнаціонального лексичного фонду. В авангарді інтеграційних процесів перебуває англійська мова, тому основним способом виникнення неологізмів стали запозичення 3 англійської мови, інтенсивне засвоєння яких відбувається завдяки інтернет-3МІ, соціальним мережам, блогам, месенджерам тощо.

У сучасному мовознавстві немає усталеного погляду на поняття «неологізм», оскільки науковці за основу беруть різні критерії для характеристики цього терміна. Енциклопедія «Українська мова» визначає неологізм так: «Слово, а також його окреме значення, вислів, які з'явилися в мові на даному етапі іiі розвитку і новизна яких усвідомлюється мовцями (загальномовні Н.) або були вжиті тільки в якомусь акті мовлення, тексті чи мові певного автора (стилістичні, або індивідуальноавторські)» [1, с. 377].

Мета дослідження - проаналізувати структурно-семантичні та функціональні особливості нової лексики, спричиненою пандемією коронавірусу, простежити засвоєння неологізмів на матеріалі інтернет-ЗМК.

Словник сучасної української мови та сленгу «Мислово» словом 2020 р. обрав «популярний» нині термін інтернаціонального походження - коронавірус, який став атрибутом (чи артефактом?) нашої доби й суттєво змінив наше життя. (Учені знають це сімейство вірусів ще з 60-их років минулого століття, але до цього року назва не вживалася за межами медичного контексту). Коронавірусна хвороба 2019 (вірус отримав назву COVID-19 (від англ. Coronavirus disease 2019), абревіатура Covid-2019 або COVID-19, яка затверджена як офіційна скорочена назва) - інфекційна хвороба, яка виникла вперше у грудні 2019 року в місті Ухань, Центральний Китай [2]. Форма вірусу схожа на корону, тому й назвали коронавірус. 
3'явившись у мові, нова лексична одиниця проходить певні етапи соціалізації й лексикалізації. Одним із способів засвоєння іншомовної лексики $є$ гібридизація - використання чужомовних елементів під час термінотворення. Такі гібридні утворення, складені одночасно з питомих та інтернаціональних морфем, відбивають ступінь засвоєння мовою запозичення, що й спостерігаємо в медійних текстах. Першу частину новозапозиченого слова активно використовують у ролі твірної основи для формування термінів різних галузей, наприклад: коронакриза, коронапаніка, коронафейк, коронаскептик, коронадисидент, коронахворий тощо. Коронакриза - криза, викликана коронавірусом і загальносвітовим карантином. Напр.: Україну чекає стрімке зростання торгового дефіциту внаслідок коронакризи. Коронапаніка - занепадницькі прогнози, поширення фейків тощо. Коронафейк - це неправдива й необгрунтована інформація про коронавірусну хворобу та ії лікування, яку розповсюджують у соціальних мережах і месенджерах. Пор.: Шахраї та коронафейки. Коронаскептик, коронадисидент - громадяни, які заперечують небезпеку або навіть саме існування інфекції COVID-19. За аналогією 3 «міленіали» з'явилися короніали (від англ. coronnials) покоління дітей, які народилися під час пандемії коронавірусу чи народяться після неї. $€$ й інше значення: так називають дітей, які зараз опановують нові практики й світ онлайн.

Синонімом до лексеми коронавірус є іншомовна абревіатура COVID, що еволюціонувала досить швидко. Оскільки ми живемо в атмосфері ковіду, то складноскорочене слово перетворилося в самостійне «ковід», від якого утворюємо нові терміни й частини мови: антиковід, ковідіворс, covid-cтрес, covid-лук, COVID-дисидентство, ковідний тощо.

Пандемія призводить до напружених соціально-психологічних ситуацій, зокрема й до розлучень, коли люди не можуть бути разом у замкненому просторі. Так виник термін ковідіворс (від англ..covid + divorce - розлучення). Ще один термін закріпився в психології - синдром covid-cmpecy. У часописі «Тиждень» зафіксовано новотвір, у якому збережена графіка мови-джерела, а зміст назви пояснено в контексті. Це вказує на те, що неолексема ще адаптується в українській мові. Напр.: Складається враження, що в Україні доволі популярне COVIDдисидентство, багато людей не вірять у вірус, вважають його не таким уже й небезпечним, ігнорують заходи безпеки, не носять масок правильно. У живому мовленні, соціальних мережах трапляється неономінація 3 негативним емоційно-експресивним забарвленням ковіdiom, утворена злиттям двох слів «ковід» й «ідіот». Сьогодні маємо два протилежних значення: людина, яка заперечує наявність пандемії й 
небезпеки від неї, порушує режим самоізоляції, вперто ігнорує протокол «соціального дистанціювання», тим самим сприяючи поширенню COVID-19, та, навпаки, та, що занадто панікує, надмірно миє руки, панічно боячись зараження, перебільшує страхи через COVID-19. Поширення слова ковід мотивувало утворення похідного прикметника ковідний. Пор.: Яка вартість лікування ковідних хворих.

Лексика медичної сфери поповнилася також новозапозиченнням caнimaйзер (від англ. sanitary), яке з'явилося й в інших національних мовах, - дезінфікуючий засіб, що використовується для запобігання передачі патогенних мікроорганізмів та дотримання елементарних правил гігієни рук. Пор: В Україні розробили санітайзер за рекомендаціями ВООЗ.

Ще зовсім недавно в активному словнику більшості людей слів «пандемія», «карантин», «обсервація» не було; вони вживалися лише в медичних наукових колах. У сучасних реаліях терміни набули нового змісту й розширили сферу функціонування. Наприклад, лексема «карантин» походить від італійського слова «quaranta», що буквально перекладається, як «час, що триває сорок днів». Раніше це була ізоляція групи людей, зараз явище набуло світового масштабу - як засіб стримування пандемії. На основі вищезгаданої медичної термінології слово увійшло до стійких словосполучень: адаптивний карантин, карантин вихідного дня. Пор., часопис «Тиждень» повідомляє: Україна прийняла режим так званого адаптивного карантину. З'явилися похідні словосполучення: карантинні канікули, карантинні челенджі. У соціальних мережах відразу після оголошення карантину виникло й миттєво розповсюдилося слово $з$ емоційно-експресивним забарвленням «карантікули» - похідне від «карантину» й «канікул». Картинку із карантину, фото з перебування в самоізоляції називають карантинка (за аналогією до валентинка). Виникло розмовно-просторічне неодієслово карантинитися.

У медіатекстах активно вживають новозапозичення локдаун, що $є$ синонімом до узвичаєного слова. За версією Collins Dictionary словом 2020 року став «локдаун» (англ.lockdown) - «введення жорстких обмежень на подорожі, соціальну взаємодію та доступ до громадських приміщень» [3]. Лексема уже адаптувалася і ввійшла до словосполучення, пор.: Арахамія розповів, що передбачатиме «інтелектуальний локдаун».

Деякі раніше вживані слова сьогодні переосмислені й сприймаються інакше, до цього спричинилися нові соціальні умови, наприклад, слово самоізолячія обмежувалося значеннями: напрямок у зовнішній політиці й 
психіатричний симптом. Наразі додалося нове - добровільне обмеження контактів із оточенням для запобігання поширенню коронавірусу.

В умовах розповсюдження коронавірусу в людей сформувалися нові норми поведінки в суспільстві: носіння маски, утримання від рукостискань, обіймів і дотримання соціальної дистанції - мінімальна відстань між людьми, якої вимагають правила карантину.

3'явилися також «контактні» - люди, які контактували з хворим на коронавірус, й «підозрілі» - так сьогодні називають людей з підозрою на інфекційне захворювання. Слово безконтактний набуло нового значення: раніше безконтактними були види спорту, ігри, а зараз $є$ безконтактна доставка їжі, продуктів тощо.

Отже, лексичні неологізми - це соціальні маркери трансформацій, характерних для суспільства в умовах глобалізованого світу. Неологізація лексики відбувається через засвоєння іншомовних слів, переважно англіцизмів, термінів інтернаціонального характеру, які поповнюють термінологічні підсистеми, зокрема медичну, адміністративну тощо; шляхом словотворення 3 використанням запозичених дериваційних засобів; завдяки активізації процесів розширення семантичного обсягу давно відомих слів. Значна частина нової лексики, очевидно, не стане загальномовним надбанням, оскільки після закінчення пандемії коронавірусу вийде 3 активного вжитку й переміститься до історизмів доби, які стануть свідченням періоду карантинних заходів та самоізоляції громадян, а деякі слова повернуться до вузькоспеціальної сфери функціонування.

\section{Література:}

1. Українська мова. Енциклопедія / В.М. Русанівський, О.О. Тараненко, М.П. Зяблюк (ред. колегія) та ін. К.: «Укр. енцикл.», 2000. 752 с.

2. Коронавірусна хвороба 2019.URL: https://uk.wikipedia.org/wiki/ Коронавірусна хвороба 2019 (дата звернення: 20.01.2021).

3. Катерина Амеліна. Локдаун - слово року від Collins Dictionary. I це ще не все. URL:https://life.liga.net/poyasnennya/news/lokdaunslovo-2020-goda-ot-collins-dictionary-i-esche-esche-ne-vse (дата звернення: 21.01.2021). 